\title{
A Study of Maternal Ophthalmic Artery Doppler Indices in Diabetics and Smokers
}

\author{
Gehan Abdelhaleim Abdelhaleim Ahmed, Elsafi Ahmed Abdalla, \\ Caroline Edward Ayad \\ Sudan University of Science and Technology, College of Medical Radiological Science, Khartoum, Sudan
}

\begin{abstract}
The aims of this study are to characterize the ophthalmic artery $(O A)$ perfusion in smoker pregnant ladies, diabetic pregnant ladies and smoker diabetic pregnant ladies using Doppler indices and to compare with normal healthy pregnancy.

The sample was divided into 4 groups: group 1 were normal healthy pregnant ladies $(N=57)$, group 2 were smokers pregnant ladies $(N=44)$, group 3 were diabetic pregnant ladies $(N=64)$, and group 4 were diabetic smoke pregnant ladies $(N=71)$ ladies. All groups were examined and assessed during the pregnancy period for $O A$ Doppler indices of both right and left eyes. The resistive index (RI), pulsatility index (PI), and mean velocity $(M V)$ were determined. Comparisons were performed between the norms and the other three groups.

Result showed significant increasing in RI,PI in the right and left eyes in all groups at $p \leq 0.000$ except in smoker pregnant ladies $p \leq 0.069$, the PI decreased in the third trimester, as well the MV decreased significantly with advancing GA. A significant differences were detected between norms and the three groups at $p \leq 0.000$

In conclusion, Doppler velocimetry is an acknowledged technique for evaluation of the RI, PI, and MV in the $O A$. Regarding the results smoking provokes perfusion changes in ophthalmic artery in smoker pregnant ladies. Thus, there are signs of an $\mathrm{OA}$ vasoconstriction and hypoperfusion . OA blood flow velocity was decreased in diabetic pregnant ladies.
\end{abstract}

Keywords: Doppler ultrasound, ophthalmic artery, pregnancy, smokers, diabetes

\section{Introduction}

Recent advances in color Doppler imaging techniques permit visualization and hemodynamic characterization of the ocular vasculature.[1,2] This technique is a noninvasive, reproducible, and easily applied method of examining hemodynamic changes in several orbital and retinal vascular diseases.[3-5]

Cigarette smoking has increased among the female population and the rates of pregnant smokers are estimated at 13\% [5,6]The cigarette has vascular effects because they are the summation of the actions of each vasoactive substance inhaled. [7,8] Cigarette smoking has been identified as a major risk factor for atherosclerotic complications in the coronary, aortic, and cerebral circulatory systems.[9] The ophthalmic artery (OA) is a vessel easily evaluated by Doppler method, since although being part of the central nervous system; it is located in the human body periphery. The OA artery presents morphological and physiological similarities with brain circulation.[10] Ophthalmic artery Doppler studies in smokers are not numerous and some results suggested indexes compatible with either vasoconstriction or vasodilatation but none of them included pregnant ladies [11-15]Cigarette smoking may be involved in development of vascular disorders in diabetes mellitus via a harmful effect on the circulation.[16] Most previous studies have investigated the effects of cigarette smoking on ocular blood flow parameters in nondiabetic smokers. [17-22]Studies on smoking during pregnancy are subject to unfairness and it depends upon many factors [23] while the role of smoking in diabetic angiopathy, retinopathy, has not been clearly established. [24-30]

To the best of our knowledge no studies in the open literature that addressed the hemodynamic profile of the ophthalmic artery was done in pregnant smokers or diabetic pregnant smokers. Herein, we examined the OA flow indices in normal pregnancy, in pregnancy with diabetes, in smoker pregnant ladies, and in diabetic smoker pregnant ladies during all pregnancy trimesters.

\subsection{Study Population}

\section{Materials and Methods}

The data of this study were obtained from Sudanese pregnant ladies attending the designated study area during the study period, with singleton pregnancies with viable fetus. Verbal consent was firstly obtained from all potential participants. The aims, benefits of the present study were explained to all participants in details. Medical, obstetric and gynecological history of all study subjects posing as (sample) were thoroughly reviewed directly from participants themselves and those with conditions that may in any way, alter the findings of the current study were excluded. Any patients with eyes disease, abnormal pregnancy or pregnancy with 
preeclampsia, or with hypertension were excluded. The sample was divided into 4 groups: group 1 were normal pregnancy $(\mathrm{N}=57)$, group 2 were pregnant smokers $(\mathrm{N}=44)$, group 3 were diabetic pregnant ladies $(\mathrm{N}=64)$, and group 4 were diabetic smoke pregnant ladies $=71$ ladies. Pregnant ladies were assessed and traced during the pregnancy period as once in first, second and third trimester for OA Doppler indices for both right and left eyes.

\subsection{Methods}

Color Doppler US High-frequency transducer (linear array transducer) (Volson E6) was used. The scans were performed with the patient supine and eyes were closed. 7.5 MHZ ultrasound scanner were used and applied with contact jelly through the closed upper lid while examiner's hand rests upon the orbital margin to minimize the pressure on the globe. Horizontal scan through the eye and orbit was performed. Depending on the direction of flow with respect to transducer, the blood flow results were displayed in either red or blue. The ophthalmic artery Doppler indices including Resistivity index (RI), pulsatility index (PI), Mean Velocity (MV) were measured in all groups for right and left eyes. Measurements in the ophthalmic arteries were determined after correction for the angle of insonation. The angle was always less than 60 degrees, and every measurement was made at a constant angle to the vessel

\subsection{Data Analyses}

Data were collected using a data collection sheets .The results were registered in the first, second and third trimester for each pregnant lady and then analyzed using SPSS Program Version 16. T-test was used to compare means .Values were expressed as Mean $\pm \mathrm{SD}$; Significant at P-value $<0.05$.

\section{Results}

Table 1 : Descriptive statistics of the measured values for Resistivity index (RI), pulsatility index (PI), Mean Velocity (MV) in all of the studied groups in first, second and third trimester

\begin{tabular}{|c|c|c|c|c|c|c|c|c|c|c|c|}
\hline $\begin{array}{l}\text { Studied } \\
\text { Groups }\end{array}$ & Site & $\mathrm{N}$ & 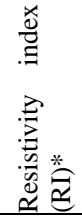 & $\sum_{\Sigma}^{\Xi}$ & 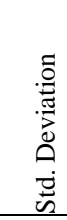 & 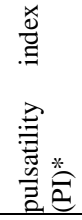 & $\stackrel{\text { ฮี }}{\stackrel{\Sigma}{\Sigma}}$ & 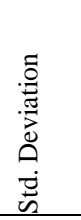 & $\begin{array}{l}\frac{3}{0} \\
\frac{0}{0} \\
> \\
\sum_{\Sigma}^{ \pm} \sum^{*}\end{array}$ & $\sum_{\Sigma}^{\Xi}$ & 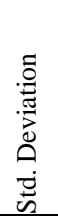 \\
\hline \multirow{6}{*}{$\begin{array}{l}\text { Normal } \\
\text { Pregnanc } \\
\mathrm{y}\end{array}$} & \multirow{3}{*}{ Left Eye } & 57 & RI1 & 0.63 & .26 & PI1 & 1.20 & 0.540 & MV1 & 7.52 & 1.79 \\
\hline & & 57 & RI2 & 1.01 & .35 & PI2 & 1.87 & 0.571 & MV2 & 6.52 & 1.46 \\
\hline & & 57 & RI3 & 1.24 & .34 & $\mathrm{PI} 3$ & 2.28 & 0.543 & MV3 & 5.18 & 1.52 \\
\hline & \multirow{3}{*}{ Right Eye } & 57 & RI1 & 0.70 & .26 & PI1 & 1.29 & 0.541 & MV1 & 7.64 & 1.49 \\
\hline & & 57 & RI2 & 1.03 & .33 & PI2 & 1.91 & 0.615 & MV2 & 6.18 & 1.41 \\
\hline & & 57 & RI3 & 1.26 & .35 & PI3 & 2.46 & 0.539 & MV3 & 4.87 & 1.74 \\
\hline \multirow{6}{*}{$\begin{array}{l}\text { Smoker } \\
\text { Pregnant } \\
\text { Ladies }\end{array}$} & \multirow{3}{*}{ Left Eye } & 44 & RI1 & 0.80 & .31 & PI1 & 1.45 & 0.33 & MV1 & 8.38 & 1.61 \\
\hline & & 44 & RI2 & 1.20 & .34 & PI2 & 2.21 & 0.44 & MV2 & 7.52 & 1.39 \\
\hline & & 44 & RI3 & 1.58 & .32 & $\mathrm{PI} 3$ & 2.84 & 0.42 & MV3 & 6.69 & 1.33 \\
\hline & \multirow{3}{*}{ Right Eye } & 44 & RI1 & 0.85 & .38 & PI1 & 1.47 & 0.30 & MV1 & 8.50 & 1.53 \\
\hline & & 44 & RI2 & 1.18 & .39 & $\mathrm{PI} 2$ & 2.16 & 0.48 & MV2 & 7.46 & 1.33 \\
\hline & & 44 & RI3 & 1.51 & .44 & PI3 & 3.47 & 4.65 & MV3 & 6.68 & 1.32 \\
\hline \multirow{6}{*}{$\begin{array}{l}\text { Diabetic } \\
\text { Pregnant } \\
\text { Ladies }\end{array}$} & \multirow{3}{*}{ Left Eye } & 64 & RI1 & 0.88 & .35 & PI1 & 1.31 & .56 & MV1 & 7.12 & 1.64 \\
\hline & & 64 & RI2 & 1.45 & .39 & PI2 & 2.57 & .69 & MV2 & 5.90 & 1.52 \\
\hline & & 64 & RI3 & 1.84 & .50 & PI3 & 3.38 & .47 & MV3 & 4.64 & 1.56 \\
\hline & \multirow{3}{*}{ Right Eye } & 64 & RI1 & 0.90 & .44 & PI1 & 1.30 & .67 & MV1 & 6.89 & 1.59 \\
\hline & & 64 & RI2 & 1.43 & .42 & PI2 & 2.62 & .77 & MV2 & 5.52 & 1.59 \\
\hline & & 64 & RI3 & 1.80 & .46 & PI3 & 3.34 & .59 & MV3 & 4.46 & 1.68 \\
\hline \multirow{6}{*}{$\begin{array}{l}\text { Smoker } \\
\text { Diabetic } \\
\text { Pregnant } \\
\text { Ladies }\end{array}$} & \multirow{3}{*}{ Left Eye } & 71 & RI1 & 0.98 & .44 & PI1 & 1.63 & .56 & MV1 & 7.43 & 1.67 \\
\hline & & 71 & RI2 & 1.35 & .40 & PI2 & 2.73 & .53 & MV2 & 6.38 & 1.64 \\
\hline & & 71 & RI3 & 1.72 & .28 & PI3 & 3.74 & .59 & MV3 & 5.30 & 1.62 \\
\hline & \multirow{3}{*}{ Right Eye } & 71 & RI1 & 1.01 & .50 & PI1 & 1.58 & .59 & MV1 & 7.80 & 1.52 \\
\hline & & 71 & RI2 & 1.43 & .38 & PI2 & 2.77 & .56 & MV2 & 6.81 & 1.56 \\
\hline & & 71 & RI3 & 1.67 & .30 & PI3 & 3.74 & .68 & MV3 & 5.58 & 1.48 \\
\hline
\end{tabular}


(RI)stands for Resistivity index, (PI)for pulsatility index, (MV) for Mean Velocity in all of the studied groups in first , second and third trimester(RI1,RI2,RI3 and PI1,PI2,PI3 and MV1,MV2,MV3)

Table 2 : Correlations between the measured values for Resistivity index (RI), pulsatility index (PI), Mean Velocity (MV) in all of the studied groups in first, second and third trimester in all pregnancy conditions .Correlation is significant at $\mathrm{p} \leq 0.05$

\begin{tabular}{|c|c|c|c|c|c|c|c|c|c|c|}
\hline $\begin{array}{l}\text { Studied } \\
\text { Group }\end{array}$ & $\stackrel{\underline{n}}{\underline{n}}$ & 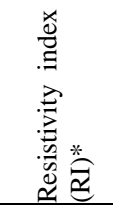 & 这 & $\infty 0$ & 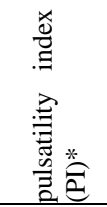 & 苞 & $\frac{.00}{5}$ & $\begin{array}{l}\frac{2}{0} \\
\frac{0}{0} \\
\stackrel{0}{>} \\
\sum_{\Sigma}^{*} \sum^{*}\end{array}$ & 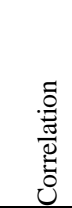 & .00 \\
\hline \multirow{4}{*}{$\begin{array}{l}\text { Normal } \\
\text { Pregnancy }\end{array}$} & \multirow{2}{*}{$\begin{array}{l}\text { Left } \\
\text { Eye }\end{array}$} & $\mathrm{R} 1 \& \mathrm{R} 2$ & .247 & .064 & P1 \& P2 & .450 & .000 & MV1 \& MV2 & .835 & .000 \\
\hline & & R2 \& R3 & .758 & .000 & P2 \& P3 & .521 & .000 & MV2 \& MV3 & .674 & .000 \\
\hline & \multirow{2}{*}{$\begin{array}{l}\text { Right } \\
\text { Eye }\end{array}$} & R1 \& R2 & .328 & .013 & P1 \& P2 & .605 & .000 & MV1 \& MV2 & .544 & .000 \\
\hline & & R2 \& R3 & .731 & .000 & $\mathrm{P} 2 \& \mathrm{P} 3$ & .725 & .000 & MV2 \& MV3 & .698 & .000 \\
\hline \multirow{4}{*}{$\begin{array}{l}\text { Smoker } \\
\text { Pregnant } \\
\text { Ladies }\end{array}$} & \multirow{2}{*}{$\begin{array}{l}\text { Left } \\
\text { Eye }\end{array}$} & R1 \& R2 & .246 & .107 & P1 \& P2 & .226 & .141 & MV1 \& MV2 & .898 & .000 \\
\hline & & $\mathrm{R} 2 \& \mathrm{R} 3$ & .373 & .013 & P2 \& P3 & .302 & .046 & MV2 \& MV3 & .910 & .000 \\
\hline & \multirow{2}{*}{$\begin{array}{l}\text { Right } \\
\text { Eye }\end{array}$} & $\mathrm{R} 1 \& \mathrm{R} 2$ & .497 & .001 & P1 \& P2 & .589 & .000 & MV1 \& MV2 & .879 & .000 \\
\hline & & R2 \& R3 & .445 & .002 & P2 \& P3 & .097 & .531 & MV2 \& MV3 & .867 & .000 \\
\hline \multirow{4}{*}{$\begin{array}{l}\text { Diabetic } \\
\text { Pregnant } \\
\text { Ladies }\end{array}$} & \multirow{2}{*}{$\begin{array}{l}\text { Left } \\
\text { Eye }\end{array}$} & R1 \& R2 & .428 & .000 & $\overline{\mathrm{P} 1 \& \mathrm{P} 2}$ & .347 & .005 & MV1 \& MV2 & .769 & .000 \\
\hline & & R2 \& R3 & .544 & .000 & P2 \& P3 & .528 & .000 & MV2 \& MV3 & .835 & .000 \\
\hline & \multirow{2}{*}{$\begin{array}{l}\text { Right } \\
\text { Eye }\end{array}$} & $\mathrm{R} 1 \& \mathrm{R} 2$ & .515 & .000 & P1 \& P2 & .245 & .051 & MV1 \& MV2 & .633 & .000 \\
\hline & & R2 \& R3 & .595 & .000 & P2 \& P3 & .261 & .038 & MV2 \& MV3 & .827 & .000 \\
\hline \multirow{4}{*}{$\begin{array}{l}\text { Smoker } \\
\text { Diabetic } \\
\text { Pregnant } \\
\text { Ladies }\end{array}$} & \multirow{2}{*}{$\begin{array}{l}\text { Left } \\
\text { Eye }\end{array}$} & $\mathrm{R} 1 \& \mathrm{R} 2$ & .567 & .000 & P1 \& P2 & .263 & .026 & MV1 \& MV2 & .722 & .000 \\
\hline & & R2 \& R3 & .500 & .000 & P2 \& P3 & .075 & .536 & MV2 \& MV3 & .840 & .000 \\
\hline & \multirow{2}{*}{$\begin{array}{l}\text { Right } \\
\text { Eye }\end{array}$} & R1 \& R2 & .540 & .000 & P1 \& P2 & .239 & .045 & MV1 \& MV2 & .847 & .000 \\
\hline & & R2 \& R3 & .544 & .000 & P2 \& P3 & .387 & .001 & MV2 \& MV3 & .663 & .000 \\
\hline
\end{tabular}

(RI)stands for Resistivity index, (PI)for pulsatility index, (MV) for Mean Velocity in all of the studied groups in first , second and third trimester(RI1,RI2,RI3 and PI1,PI2,PI3 and MV1,MV2,MV3)

Table 3 : Paired Samples test showed the Paired Differences between the measured values for Resistivity index (RI), pulsatility index (PI), Mean Velocity (MV) in all of the studied groups in first, second and third trimester in all pregnancy conditions. Correlation is significant at $p \leq 0.05$

\begin{tabular}{|c|c|c|c|c|c|c|c|c|c|c|c|c|c|c|c|}
\hline \multirow{2}{*}{$\begin{array}{l}\text { Studied } \\
\text { Group }\end{array}$} & \multirow[b]{2}{*}{ Site } & \multirow{2}{*}{\multicolumn{2}{|c|}{ RI }} & \multicolumn{2}{|c|}{$\begin{array}{l}\text { Paired } \\
\text { Differences }\end{array}$} & \multirow[b]{2}{*}{ 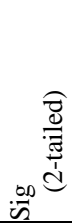 } & \multirow[t]{2}{*}{ PI } & \multicolumn{2}{|c|}{$\begin{array}{l}\text { Paired } \\
\text { Differences }\end{array}$} & \multirow[b]{2}{*}{ 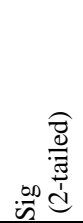 } & \multicolumn{2}{|l|}{ MV } & \multicolumn{2}{|c|}{$\begin{array}{l}\text { Paired } \\
\text { Differences }\end{array}$} & \multirow[b]{2}{*}{ 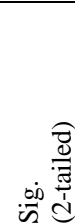 } \\
\hline & & & & Mean & $\begin{array}{l}\text { STD } \\
\mathrm{V}\end{array}$ & & & Mean & STDV & & & & $\begin{array}{l}\text { Mea } \\
n\end{array}$ & STDV & \\
\hline \multirow{4}{*}{$\begin{array}{l}\text { Normal } \\
\text { Pregnan } \\
\text { cy }\end{array}$} & \multirow{2}{*}{$\begin{array}{l}\text { Left } \\
\text { Eye }\end{array}$} & $\begin{array}{l}\mathrm{R} 1 \\
\mathrm{R} 2\end{array}$ & - & -.381 & .39 & .000 & $\begin{array}{ll}\mathrm{P} 1 & - \\
\mathrm{P} 2\end{array}$ & -.67 & 0.58 & .000 & $\begin{array}{l}\text { MV1 } \\
\text { MV2 }\end{array}$ & & 1.00 & .98 & .000 \\
\hline & & $\begin{array}{l}\text { R2 } \\
\text { R3 }\end{array}$ & - & -.233 & .24 & .000 & $\begin{array}{l}\mathrm{P} 2 \\
\mathrm{P} 3\end{array}$ & -.41 & 0.54 & .000 & $\begin{array}{l}\text { MV2 } \\
\text { MV3 }\end{array}$ & - & 1.34 & 1.20 & .000 \\
\hline & \multirow{2}{*}{$\begin{array}{l}\text { Right } \\
\text { Eye }\end{array}$} & $\begin{array}{l}\mathrm{R} 1 \\
\mathrm{R} 2\end{array}$ & - & -.329 & .35 & .000 & $\begin{array}{l}\mathrm{P} 1 \\
\mathrm{P} 2\end{array}$ & -.62 & 0.51 & .000 & $\begin{array}{l}\text { MV1 } \\
\text { MV2 }\end{array}$ & - & 1.45 & 1.39 & .000 \\
\hline & & $\begin{array}{l}\mathrm{R} 2 \\
\mathrm{R} 3\end{array}$ & - & -.227 & .25 & .000 & $\begin{array}{ll}\text { P2 } & - \\
\text { P3 }\end{array}$ & -.55 & 0.43 & .000 & $\begin{array}{l}\text { MV2 } \\
\text { MV3 }\end{array}$ & - & 1.31 & 1.26 & .000 \\
\hline \multirow{4}{*}{$\begin{array}{l}\text { Smoker } \\
\text { Pregnan } \\
\text { t Ladies }\end{array}$} & \multirow{2}{*}{$\begin{array}{l}\text { Left } \\
\text { Eye }\end{array}$} & $\begin{array}{l}\mathrm{R} 1 \\
\mathrm{R} 2\end{array}$ & - & -.404 & .40 & .000 & $\begin{array}{ll}\mathrm{P} 1 & - \\
\mathrm{P} 2\end{array}$ & -.75 & 0.48 & .000 & $\begin{array}{l}\text { MV1 } \\
\text { MV2 }\end{array}$ & - & 0.85 & 0.71 & .000 \\
\hline & & $\begin{array}{l}\mathrm{R} 2 \\
\mathrm{R} 3\end{array}$ & - & -.384 & .37 & .000 & $\begin{array}{ll}\text { P2 } & - \\
\text { P3 }\end{array}$ & -.62 & 0.51 & .000 & $\begin{array}{l}\text { MV2 } \\
\text { MV3 }\end{array}$ & - & 0.82 & 0.58 & .000 \\
\hline & \multirow{2}{*}{$\begin{array}{l}\text { Right } \\
\text { Eye }\end{array}$} & $\begin{array}{l}\mathrm{R} 1 \\
\mathrm{R} 2\end{array}$ & - & -.333 & .39 & .000 & $\begin{array}{ll}\mathrm{P} 1 & - \\
\mathrm{P} 2\end{array}$ & -.68 & 0.39 & .000 & $\begin{array}{l}\text { MV1 } \\
\text { MV2 }\end{array}$ & - & 1.04 & 0.73 & .000 \\
\hline & & $\begin{array}{l}\mathrm{R} 2 \\
\mathrm{R} 3\end{array}$ & - & -.321 & .44 & .000 & $\begin{array}{ll}\mathrm{P} 2 & - \\
\mathrm{P} 3\end{array}$ & -1.3 & 4.63 & .069 & $\begin{array}{l}\text { MV2 } \\
\text { MV3 }\end{array}$ & - & 0.78 & .68 & .000 \\
\hline \multirow{4}{*}{$\begin{array}{l}\text { Diabetic } \\
\text { Pregnan } \\
\text { t Ladies }\end{array}$} & \multirow{2}{*}{$\begin{array}{l}\text { Left } \\
\text { Eye }\end{array}$} & $\begin{array}{l}\mathrm{R} 1 \\
\mathrm{R} 2 \\
\end{array}$ & - & -.575 & .40 & .000 & $\begin{array}{ll}\text { P1 } & - \\
\text { P2 }\end{array}$ & -1.2 & 0.72 & .000 & $\begin{array}{l}\text { MV1 } \\
\text { MV2 }\end{array}$ & - & 1.22 & 1.08 & .000 \\
\hline & & $\begin{array}{l}\text { R2 } \\
\text { R3 }\end{array}$ & - & -.385 & .43 & .000 & $\begin{array}{ll}\text { P2 } & - \\
\text { P3 }\end{array}$ & -.81 & 0.60 & .000 & $\begin{array}{l}\text { MV2 } \\
\text { MV3 }\end{array}$ & - & 1.26 & .88 & .000 \\
\hline & \multirow{2}{*}{$\begin{array}{l}\text { Right } \\
\text { Eye }\end{array}$} & $\begin{array}{l}\mathrm{R} 1 \\
\mathrm{R} 2\end{array}$ & - & -.528 & .42 & .000 & $\begin{array}{ll}\mathrm{P} 1 & - \\
\mathrm{P} 2\end{array}$ & -1.3 & 0.89 & .000 & $\begin{array}{l}\text { MV1 } \\
\text { MV2 }\end{array}$ & - & 1.36 & 1.36 & .000 \\
\hline & & $\begin{array}{l}\text { R2 } \\
\text { R3 }\end{array}$ & - & -.370 & .40 & .000 & $\begin{array}{l}\mathrm{P} 2 \\
\mathrm{P} 3\end{array}$ & -.72 & 0.84 & .000 & $\begin{array}{l}\text { MV2 } \\
\text { MV3 }\end{array}$ & - & 1.05 & 0.96 & .000 \\
\hline $\begin{array}{l}\text { Smoker } \\
\text { Diabetic }\end{array}$ & $\begin{array}{l}\text { Left } \\
\text { Eye }\end{array}$ & $\begin{array}{l}\text { R1 } \\
\text { R2 }\end{array}$ & - & -.368 & .39 & .000 & $\begin{array}{l}\text { P1 - } \\
\text { P2 }\end{array}$ & -1.1 & 0.66 & .000 & $\begin{array}{l}\text { MV1 } \\
\text { MV2 }\end{array}$ & - & 1.05 & 1.23 & .000 \\
\hline
\end{tabular}


A Study Of Maternal Ophthalmic Artery Doppler Indices In Diabetics And Smokers

\begin{tabular}{|c|c|c|c|c|c|c|c|c|c|c|c|c|c|}
\hline \multirow[t]{3}{*}{$\begin{array}{l}\text { Pregnan } \\
\text { t Ladies }\end{array}$} & & $\begin{array}{l}\text { R2 } \\
\text { R3 }\end{array}$ & -.370 & .35 & .000 & $\begin{array}{l}\text { P2 } \\
\text { P3 }\end{array}$ & -1.0 & 0.77 & .000 & $\begin{array}{ll}\text { MV2 } & - \\
\text { MV3 }\end{array}$ & 1.08 & 0.92 & .000 \\
\hline & \multirow{2}{*}{$\begin{array}{l}\text { Right } \\
\text { Eye }\end{array}$} & $\begin{array}{l}\text { R1 } \\
\text { R2 }\end{array}$ & -.426 & .43 & .000 & $\begin{array}{ll}\text { P1 } & - \\
\text { P2 }\end{array}$ & -1.1 & 0.71 & .000 & $\begin{array}{l}\text { MV1 } \\
\text { MV2 }\end{array}$ & 0.98 & 0.85 & .000 \\
\hline & & $\begin{array}{l}\text { R2 } \\
\text { R3 }\end{array}$ & -.238 & .33 & .000 & $\begin{array}{l}\mathrm{P} 2 \\
\text { P3 }\end{array}$ & -.96 & 0.70 & .000 & $\begin{array}{l}\text { MV2 } \\
\text { MV3 }\end{array}$ & 1.23 & 1.25 & .000 \\
\hline
\end{tabular}

Table 4 : T-test showed the difference between the measured values for Resistivity index (RI), pulsatility index (PI), Mean Velocity (MV) comparison between the examined groups and normal healthypregnant ladies in the three trimesters .

\begin{tabular}{|c|c|c|c|c|c|}
\hline & Site & Parameters & $\begin{array}{l}\text { Smoker Pregnant } \\
\text { Ladies }\end{array}$ & $\begin{array}{l}\text { Diabetic } \\
\text { Ladies }\end{array}$ & $\begin{array}{l}\text { Smoker Diabetic } \\
\text { Pregnant Ladies }\end{array}$ \\
\hline \multirow{18}{*}{$\begin{array}{l}\text { Normal } \\
\text { Pregnanc } \\
\text { y }\end{array}$} & \multirow{3}{*}{ Left Eye } & RI & 0.003 & 0.000 & 0.000 \\
\hline & & RI2 & 0.025 & 0.000 & 0.000 \\
\hline & & RI3 & 0.038 & 0.000 & 0.000 \\
\hline & \multirow{3}{*}{ Right Eye } & RI & 0.000 & 0.000 & 0.000 \\
\hline & & RI2 & 0.000 & 0.000 & 0.000 \\
\hline & & RI3 & 0.000 & 0.000 & 0.000 \\
\hline & \multirow{3}{*}{ Left Eye } & PI1 & 0.000 & 0.000 & 0.000 \\
\hline & & PI2 & 0.000 & 0.000 & 0.000 \\
\hline & & $\mathrm{PI} 3$ & 0.000 & 0.000 & 0.000 \\
\hline & \multirow{3}{*}{ Right Eye } & PI1 & 0.000 & 0.000 & 0.000 \\
\hline & & PI2 & 0.000 & 0.000 & 0.000 \\
\hline & & PI3 & 0.000 & 0.000 & 0.000 \\
\hline & \multirow{3}{*}{ Left Eye } & MV1 & 0.000 & 0.000 & 0.000 \\
\hline & & MV2 & 0.000 & 0.000 & 0.000 \\
\hline & & MV3 & 0.000 & 0.000 & 0.000 \\
\hline & \multirow{3}{*}{ Right Eye } & MV1 & 0.000 & 0.000 & 0.000 \\
\hline & & MV2 & 0.050 & 0.020 & 0.000 \\
\hline & & MV3 & 0.010 & 0.044 & 0.000 \\
\hline
\end{tabular}

Correlation is significant at $\mathrm{p} \leq 0.05$

\section{Discussion}

This study analyzed the correlation between ophthalmic Doppler indices and gestational age (pregnancy trimesters) in healthy ladies with singleton pregnancies. In normal pregnant ladies group the RI, PI, MV were measured in each trimester for both eyes. Results showed no significant difference was detected between RI in first trimeater and RI in the second trimester for the left eye, while the readings in the second trimester for RI2-RI3,PI1,PI2,PI3 and MV1,MV2,MV3 showed significant difference for both left and right eyes(Table1 and table2)

Previous studies assessed the orbital circulation using ultrasonography, and patterns of orbital vessels normality have been described. The importance of this examination was first shown in ophthalmologic diseases. $[31,32]$

Before abnormalities can be recognized in the eye, measurements must be achieved in healthy pregnant ladies, and the variation affecting the normal data should be resoluted. Therefore the current study analyzed the correlation between ophthalmic Doppler indices (RI, PI, and MV) and GA progress in healthy patients with singleton pregnancies.

Hata et al [33]were the first to use Doppler velocimetry of the ophthalmic artery in the assessment of pregnant women. Several authors have since evaluated this method during pregnancy, especially in patients with hypertension.[34,35,36], Ocular Doppler sonography has been shown to be an perfect, objective, and capable method in the evaluation of preeclampsia .Yet, agreement on the reference values for the flow parameters of ocular Doppler sonography in normal pregnancy has not yet been established.[37] When comparing our results with the previous similar studies, MacKenzie et al [38] evaluated ophthalmic Doppler indices in normal pregnant ladies and reported that the ophthalmic artery (RI) decreased, whereas the (PI) remained unchanged with advancing gestational age (GA).However, Ohno et al [35] reported an inverse correlation between PI and GA values in normal pregnant ladies, and Carneiro et al [36] reported no significant correlation between Doppler indices (including the RI and PI) in healthy pregnant women.

In the second group, (the smoker pregnant ladies) we found that the changes of RI,PI for the left eye did not differ significantly as the GA increased, however significant changes were detected for all of the parameters (RI,PI,MV) in the second and third trimesters for both eyes .However no significant changes between PI1 and PI2 of the right eye in smoker pregnant ladies $\mathrm{p} \leq .531$. In the fourth group (the smoker diabetic pregnant ladies); Doppler indices for RI,PI,MV were statistically differ as the gestational age increased except for PI in the second trimester (Table 2,3). When comparing the normal pregnant values(Controls) with the 
smoker pregnant ladies and the smoker diabetic pregnant ladies ; a significant difference were detected in all trimesters (Table4)

The effects of smoking on the vessels are due to vasoactive substance inhaled [8]. Doppler indices of OA allocate us to characterize the hemodynamic changes in vessel. In the current study, we evaluated the readings of the Doppler indices in the $\mathrm{OA}$ and compared the findings with normal pregnant ladies readings.(table4)

There are few studies characterizing the effects of cigarette in OA and they all didn't discuss the effects in pregnant ladies [11-15]. Researchers, assessing the effects of smoking, observed lower peak systolic velocity in OA of smokers without change in end diastolic velocity and RI, compared to controls[11], but other researchers, report that the peak systolic velocity was lower in smokers[12]. These two authors did not specify how long ago was the use of cigarettes [11,12] Similarly; our study did not consider the duration of smoking nor the type (cigarettes,sigar, shisha, handmade cigarettes (tobacco roll), or other sourse of tobacco smoking) or the numbers of cigareates/day in all individuals in the two groups. We correlated the variables in each trimester, our findings was in disagreement with those studies.

In previous studies about the Doppler velocimetry in smokers, the RI and PI show the arterial resistance to blood distal flow, reflecting vasoconstriction and hypoperfusion. Low PI values indicate ophthalmic artery hyperperfusion and hyperaemia [39,40]. A study evaluated smokers in advanced phase of using up, found an association between smoking and changes in blood flow in the ophthalmic artery [13] they found that the mean Doppler values were consistent with hypoperfusion, with low peak systolic velosity and higher RI compared to controls.

Other studies, found results consistent with vasodilatation, with higher peak systolic velosity lower RI compared to controls. $[14,15]$ These studies, are not in concordance with our results. We justify our results of finding the correlation between smoking and ophtalmic artery perfusion pattern is that there is signs of vasoconstriction. Our results finding reflects that the OA Doppler indices in smokers is compatible with hypoperfusion and vaso constriction.In diabetic pregnant ladies group; there are significant increasing in RI as the GA increased for both right and left eyes as well as the PI and MV was found to be significantly changed in second and third trimester.(table2,3). When comparing the third group (diabetic pregnant ladies) with controls significant differences were detected between the diabetics and normal pregnancy (table4).

Studies have mentioned that the association of smoking and diabetic retinopathy has not been clear [41]. It was reported that retinopathy has been associated with glycemic control and not smoking state. [42] Some studies have reported no association with smoking and retinopathy in type 2 diabetes. [42,43] The United Kingdom Diabetic study was done to determine risk factors related to the incidence and progression of diabetic retinopathy . The development of retinopathy was associated with glycemia and higher blood pressure, but not smoking. [44] Thus in type 2 patients, the effects of smoking on diabetic retinopathy is not clear. [41]

Using color Doppler sonography, Mendivil and associates [45]and Mendivil and Cuartero [46] reported that ocular blood flow velocity was decreased in diabetic patients with diabetic retinopathy . This was in concordance with our results.

In a study done by Khan.et al ; 2014 [47] , peak systolic velosity was increased in diabetic. Reduced cellular oxygenation in diabetes may demand a compensatory increase in vascular flow.[48] This justified our result is that the MV was increased .Increasing in RI in our study may be due to downstream vascular changes related to diabetes.[49]

Regarding the results (highly significant changes of Doppler indices in group four during the pregnancy period) it showed that smoking has harmful effects on patients with diabetes. Smoking increases diabetic incidence and aggravates glucose homeostasis and chronic diabetic complications.

\section{Conclusion}

Smoking provokes perfusion changes in ophthalmic artery in smoker pregnant ladies. Thus, there are signs of an ophthalmic artery vasoconstriction and hypoperfusion. OA blood flow velocity was decreased in diabetic patients

\section{References}

[1]. Guthoff RF, Berger RW, Winkler P, et al: Doppler sonography of the ophthalmic and central retinal vessels. Arch Ophthalmol 109:532, 1991

[2]. Lieb WE, Cohen SM, Merton DA, et al: Color Doppler imaging of the eye and orbit. Arch Ophthalmol 109:527, 1991

[3]. Erickson SJ, Hendrix LE, Massaro BM, et al: Color Doppler flow imaging of the normal and abnormal orbit. Radiology 173:511, 1989

[4]. Lieb WE: Color Doppler ultrasonography of the eye and orbit. Curr Opinion Ophthalmol 4:68, 1993 5. Regillo CD, Sergott RC, Ho AC, et al: Hemodynamic alterations in the acute retinal necrosis syndrome. Ophthalmology 100:1171, 1993

[5]. Iglesias R, Jha P, Pinto M, Costa e Silva VL, Godinho J. Controle do Tabagismo no Brasil. Banco Internacional para Reconstrução e Desenvolvimento/ Banco Mundial 1818 H Street, NW Washington, DC 20433, 2007. 
[6]. CDC. Reprodutive Health.Pregnancy Risk Assessment and Monitoring System (PRAMS) $2008 . \quad$ Available in http://www.cdc.gov/reproductivehealth/TobaccoUsePregnancy/. Accessed in 11/ 28/2012.

[7]. ACS (American Cancer Society. Available in www.cancer.org/cancer/cancercauses/tobaccocancer/cigarettesmoking/index. Last Medical Review : 08/11/2012. Accessed in 11/ 28/2012

[8]. Salafia C, Shiverick K. Cigarette Smoking and Pregnancy II: Vascular Effects. Placenta. 1999; 20: $273-279$.

[9]. Fielding JE. Smoking: health effects and control (1). N Engl J Med. 1985;313:491-498.

[10]. Bill A. Blood circulation and fluid dynamics in the eye. Physiol Rev 1975; 55:383-417

[11]. Steigerwalt Jr RD. Laurora G, Incandela L, Cesarone MR, Belcaro GV, Sanctis MT.Ocular and Orbital Blod Flow in Cigarette Smokers. Retina, the Journal of Retinal and Vitreous Diseases 2000; Vol $20 \mathrm{n} 4$.

[12]. Williamson TH, Lowe GDO, Baxter GM. Influence of age, systemic blood pressure, smok-ing, and blood viscosity on orbital blood velocities. British Journal of Ophthalmology 1995; Jan;79(1):17-22.

[13]. Ergýn A, Akarsu C, Baydar S. Effect of Cigarette Smoking on the Blood Flow Velocities in the Ophthalmic and Central Retinal Arteries. Ret - Vit 2005: $13: 125-128$.

[14]. Satici A, Karaoglanoglu M, Gürler B, Güzey M, Oguz H. The Effects of Chronic Smoking on Ocular Hemodynamics. Ret-vit 1999; 7:221-228

[15]. Kaiser HJ, Schoetzau A, Flammer J. Blood flow velocity in the extraocular vessels in chronic smokers. British Journal of Ophthalmology 1997; 81:133-135.

[16]. Tsuneaki Omae, Taiji Nagaoka, and Akitoshi Yoshida Effects of Habitual Cigarette Smoking on Retinal Circulation in Patients With Type 2 DiabetesIOVS j March 2016 j Vol. 57 j No. 3 j 1346

[17]. Robinson F, Petrig BL, Riva CE. The acute effect of cigarette smoking on macular capillary blood flow in humans. Invest Ophthalmol Vis Sci. 1985;26:609-613.

[18]. Tamaki Y, Araie M, Nagahara M, Tomita K. Acute effects of cigarette smoking on tissue circulation in human optic nerve head and choroid-retina. Ophthalmology. 1999;106:564-569.

[19]. Kaiser HJ, Schoetzau A, Flammer J. Blood flow velocity in the extraocular vessels in chronic smokers. Br J Ophthalmol.1997;81:133-135.

[20]. Williamson TH, Lowe GD, Baxter GM. Influence of age, systemic blood pressure, smoking, and blood viscosity on orbital blood velocities. Br J Ophthalmol. 1995;79:17-22.

[21]. Steigerwalt RD Jr, Laurora G, Incandela L, Cesarone MR,Belcaro GV, De Sanctis MT. Ocular and orbital blood flow in cigarette smokers. Retina. 2000;20:394-397.

[22]. Morgado PB, Chen HC, Patel V, Herbert L, Kohner EM. The acute effect of smoking on retinal blood flow in subjects with and without diabetes. Ophthalmology. 1994;101:1220-1226.

[23]. Regules JMA, Vilchez PM, Asunción Villalba AG, Sanchez F, Castillo JDC. Validez De Distintas Medidas De Consumo De Tabaco Durante El Embarazo: Especificidad, Sensibilidad Y Puntos De CorteDónde Y Cuándo.Rev Esp Salud Pública 2008; 82: 535-545

[24]. Paetkau ME, Boyd TA, Winship B, Grace M. Cigarette smoking and diabetic retinopathy. Diabetes. 1977;26:46-49.

[25]. Nielsen MM, Hjollund E. Smoking and diabetic microangiopathy. Lancet. 1978;2:533-534.

[26]. Walker JM, Cove DH, Beevers DG, et al. Cigarette smoking, blood pressure and the control of blood glucose in the development of diabetic retinopathy. Diabetes Res. 1985;2:183-186.

[27]. Muhlhauser I, Sawicki P, Berger M. Cigarette-smoking as a risk factor for macroproteinuria and proliferative retinopathy in type 1 (insulin-dependent) diabetes. Diabetologia. 1986;29:500-502.

[28]. Marshall G, Garg SK, Jackson WE, Holmes DL, Chase HP. Factors influencing the onset and progression of diabetic retinopathy in subjects with insulin-dependent diabetes mellitus. Ophthalmology. 1993;100:1133-1139.

[29]. Ballard DJ, Melton LJ III, Dwyer MS, et al. Risk factors for diabetic retinopathy: a population-based study in Rochester, Minnesota. Diabetes Care. 1986;9:334-342.

[30]. Moss SE, Klein R, Klein BE. Association of cigarette smoking with diabetic retinopathy. Diabetes Care. 1991;14:119-126.

[31]. Lieb WE, Cohen SM, Merton DA, Shields JA, Mitchell DG,Goldberg BB. Color Doppler imaging of the eye and orbit.Arch Ophthalmol 1991; 103:527-531.

[32]. Erickson SJ, Hendrix LE, Massaro BM, et al. Color Dopplerflow imaging of the normal and abnormal orbit. Radiology 1989; 173:511-516.

[33]. Hata T, Senoh D, Hata K, Kitao M. Ophthalmic arteryvelocimetry in pregnant women. Lancet 1992; 340:182-183.

[34]. Ayaz T, Akansel G, Hayirlioglu A, Arslan A, Suer N, Kuru I.Ophthalmic artery color Doppler ultrasonography in mildto-moderate preeclampsia. Eur J Radiol 2003; 46:244-249.

[35]. Ohno Y, Kawai M, Wakahara Y, Kitagawa T, Kakihara M,Arii Y. Ophthalmic artery velocimetry in normotensive and preeclamptic women with or without photophobia. ObstetGynecol 1999; 94:361-363.

[36]. Carneiro RS, Sass N, Diniz AL, Souza EV, Torloni MR, MoronAF. Ophthalmic artery Doppler velocimetry in healthy pregnancy.Int J Gynaecol Obstet 2008; 100:211-215;

[37]. Barbosa AS. Estudo da Associação entre as ManifestaçõesOftálmicas da Pré-eclâmpsia Grave e os Parâmetros de Fluxo Sanguíneo das Artérias Oftálmica e Central da Retinaao Ecodoppler Ocular. Belo Horizonte, Brazil: Tese (Doutorado), Universidade Federal de Minas Gerais; 2004.

[38]. MacKenzie F, De Vermette R, Nimrod C, Boisvert D,Jackson B. Doppler sonographic studies on the ophthalmic and central retinal arteries in the gravid woman.J Ultrasound Med 1995; 14:643-647.

[39]. Ohno Y, Kawai M, Wakahara Y, Kitagawa T, Kakihara M, Arii Y. Ophthalmic artery veloc-imetry in normotensive and preeclamptic women with or without photophobia. Obstet Gynecol 1999;94(3):361-363.

[40]. Thompson RS, Trudinger BJ, Cook CM. Doppler ultrasound waveform indices: A/B ratio, pulsatilityindex, Pourcelot ratio. BrJ Obstet Gynaecol 1988;95:581-588.

[41]. Sang Ah Chang,Smoking and Type 2 Diabetes Mellitus Diabetes Metab J. 2012 Dec; 36(6): 399-403.

[42]. Guillausseau PJ, Massin P, Charles MA, Allaguy H, Guvenli Z, Virally M, Tielmans D, Assayag M, Warnet A, Lubetzki J. Glycaemic control and development of retinopathy in type 2 diabetes mellitus: a longitudinal study. Diabet Med. 1998;15:151-155.

[43]. Moss SE, Klein R, Klein BE. Cigarette smoking and ten-year progression of diabetic retinopathy.Ophthalmology. 1996;103:14381442 .

[44]. Stratton IM, Kohner EM, Aldington SJ, Turner RC, Holman RR, Manley SE, Matthews DR. UKPDS 50: risk factors for incidence and progression of retinopathy in type II diabetes over 6 years from diagnosis.Diabetologia. 2001;44:156-163. 
[45]. Mendivil A, Cuartero V, Mendivil MP: Ocular blood flow velocities in patients with proliferative diabetic retinopathy and healthy volunteers: A prospective study. Br J Ophthalmol 79:413, 1995

[46]. Mendivil A, Cuartero V: Ocular blood flow velocities in patients with proliferative diabetic retinopathy after scatter photocoagulation: Two years of follow-up. Retina 16:222, 1996

[47]. Khan Adeeb Alam, Sharma Mayank, Rizvi Syed Wajahat Ali, Amitava Abadan Khan, Siddiqui Ziya, and Siddiqui Mohammed Azfar .Alteration in Hemodynamic Parameters in Ophthalmic and Central Retinal Arteries in Indian Patients with Increasing Grade of Diabetic Retinopathy Austin J Clin Ophthalmol - Volume 1 Issue 1 - 2014

[48]. Numata K, Tanaka K, Kiba T, et al: Use of hepatic tumor index on color Doppler sonography for differentiating large hepatic tumors. AJR 168:991, 1997

[49]. Numata K, Tanaka K, Mitsui K, et al: Flow characteristics of hepatic tumors at color Doppler sonography: Correlation with arteriographic findings. AJR 160:515,1993 